\title{
Jesuits, Protestants, and Africa before the Twentieth Century
}

\author{
Festo Mkenda, s.J.
}

Sixteenth-century Africa was anything but a "dark continent" for the Jesuits. Their early missionary imagination clearly included Africa, and parts of the continent received Jesuits from as early as 1548. By 1561, Gonçalo da Silveira (1526-61) had penetrated the interior of southern Africa and had succeeded in baptizing one Monomotapa, king of the Shona people of today's Zimbabwe. Around the same period, a small band of Jesuits had entered the fabled land of Prester John, constituting the then unmapped Abyssinia, also known as Ethiopia Superior, and had succeeded in establishing a mission to Catholicize a country that was staunchly Orthodox. Mostly tormented and at times persecuted, that mission lasted for close to a century. Within the same sixteenth century, the Jesuits had made inroads into the old Kongo Kingdom, taking part in a Catholic mission that had already matured into a local church whose bishop had been the king's own son, Henry (c.1495-1531), described as the "first African bishop south of the Sahara." Similar Jesuit missions in Mozambique and Angola lasted until the Society was suppressed in Portuguese dominions in 1759.

Jesuits were not the only Catholic missionaries in Africa in that period. Other religious congregations also evangelized in regions that were under Portuguese influence. However, the Jesuit imprint on the so-called second wave of Christian evangelization of the African continent was significant. As Dr. Frederic Perry Noble (b. c.1863) — son of a Congregational pastor, a notable critic of Catholic missions in Africa, and secretary of the 1893 Chicago Congress on Africa-would put it, "He [the Jesuit], despite the activity of the Capuchin, Dominican, Franciscan, Lazarist and other orders, is the dominant figure in the missions of the sixteenth and seventeenth centuries. He compels us to center our vision on him until the coming of Lavigerie."2 Noble even refers to

1 John Baur, 2000 Years of Christianity in Africa: An African Church History, 2nd ed. (Nairobi: Paulines Publications Africa, 2009 [1994]), 59.

2 Frederic Perry Noble, The Redemption of Africa: A Story of Civilization, 2 vols. (New York: Young People's Missionary Movement, 1899), 1:361.

(C) FESTO MKENDA, S.J., 2018 | DOI 10.1163/9789004347151_003

This is an open access chapter distributed under the terms of the prevailing CC-BY-NC-ND License. 
Cardinal Charles Lavigerie (1825-92), founder of the Missionaries of Africa, as "the Loyola of Africa."

Africa's middle Christianity, in which Jesuits became such dominant players, extended from the beginnings of the padroado 4 in the fifteenth century to the waning of Portugal's exclusive patronage over the continent. That waning was well under way in the middle of the eighteenth century. Shortly after the Jesuits were sent away from Mozambique and Angola, Dominicans too were shown the exit door. Catholic missions in these parts of Africa disappeared almost completely and, together with them, any semblance of Catholicism beyond a few devotional items and practices, and ruins of churches. ${ }^{5}$

Although they left Protestants back in Europe, Jesuits of that second wave of evangelization never encountered their denominational competitors on the African soil, save for the brief but extremely interesting experience of Guy Tachard (1651-1712) and his companions in the midst of Dutch Calvinist colonists at the Cape in today's South Africa. ${ }^{6}$ Even if the Reformation in Europe influenced their missionary method and agenda, ${ }^{7}$ the Jesuits in Africa could go about their business as if Protestantism never existed. In Ethiopia, they campaigned to bring Orthodox Christianity into union with Rome; ${ }^{8}$ in eastern Africa, they lamented the ubiquity of Muslim obstruction; ${ }^{9}$ and in the western parts of south central Africa, they talked about indigenous religious practices

3 Ibid., 396.

4 The right of patronage granted to Portugal by popes according to which Portuguese kings took responsibility for the administration of local churches and missionary evangelization in newly acquired overseas territories.

5 David Livingstone and Charles Livingstone, Narrative of an Expedition to the Zambesi and Its Tributaries; And of the Discovery of the Lakes Shirwa and Nyassa, 1858-1864 (London: John Murray, 1865), 204.

6 Guy Tachard, A Relation of the Voyage to Siam: Performed by Six Jesuits Sent by the French King, to the Indies and China in the Year 1685 (Bangkok: White Lotus Press, 1999 [1688]), 33-80.

7 See Elias Kiptoo Ngetich, "Catholic Counter-Reformation: A History of the Jesuits' Mission to Ethiopia 1557-1635," Studia historiae ecclesiasticae 42, no. 2 (2016): 104-15; also John K. Thornton, "Afro-Christian Syncretism in the Kingdom of Kongo," Journal of African History 54, no. 1 (2013): 53-77, here 67-68, and Thornton, "Conquest and Theology: The Jesuits in Angola, 1548-1650," Journal of Jesuit Studies 1 (2014): 245-59, here 250.

8 Jerome Lobo, A Voyage to Abyssinia, trans. Samuel Johnson (London: Elliot and Kay, 1789), 79; also see "Introduction" to Some Records of Ethiopia, 1593-1646: Being Extracts from The History of High Ethiopia or Abassia by Manoel de Almeida Together with Bahrey's History of the Galla, trans. and ed. C.F. [Charles Fraser] Beckingham and G.W.B. [George Wynn Brereton] Huntingford (Aldershot: Ashgate, 1954), xxi-xlix, here xxi.

9 See Hubert Chadwick, Life of the Venerable Gonçalo da Silveira of the Society of Jesus: Pioneer Missionary and Proto-martyr of South Africa (London: Manresa Press, 1910), 89-91. 
and wondered whether or not they could be accommodated into their version of Christianity. ${ }^{10}$ At that time, Protestantism may have been imagined as a formidable foe, but, for Jesuits in Africa, it was one that was far away.

Then still in their first centuries of existence, Protestants busied themselves building foundations in northern Europe while Catholics explored new grounds in Africa, Asia, and the Americas. ${ }^{11}$ The objective of the Propaganda Fide, established in 1622 , is to be understood within these parameters: not only "to regain the faithful in all those parts of the world where Protestantism had been established" but also "to bring the light of the true faith to heathen lands." And this was to be achieved partly by organizing "into an efficient corps the numerous missionary enterprises for the diffusion of the Gospel in pagan lands." ${ }^{12}$ In the imagination of sixteenth- and seventeenth-century Europe, Africa was the quintessential "pagan land," and Jesuits stepped forward with determination to tame the African religious wildness, even "up to [the point of] shedding blood and being sacrificed for the faith."13

Protestants, then hardly organized for missions, would only encounter Jesuits of this period in Africa in retrospect as they passed comment on their earlier achievements, sometimes admiring them and sometimes disparaging them. The failure of the Church Missionary Society (CMs) to make headway in Ethiopia in the early nineteenth century would, for example, be blamed on "the intrigues of the Jesuits" as discerned in the tales of their missions in that country in the sixteenth and seventeenth centuries. ${ }^{14}$ Toward the end of the nineteenth century, a Protestant critic of the Jesuits would write more generally that

while the Mission field was almost exclusively in the hands of Rome, the Jesuits, in the teeth of the Papal authorities, did much as they pleased;

$10 \quad$ See Thornton, "Conquest and Theology," 68-70.

11 See Diarmaid MacCulloch, A History of Christianity: The First Three Thousand Years (London: Penguin Books, 2009), 216.

12 Peter Guilday, "The Congregation de Propaganda Fide (1622-1922)," Catholic History Review 6 , no. 4 (1921): $47^{-}-94$, here 48 o.

13 See words of the caption in Latin of a seventeenth-century allegorical engraving of Africa from Matthias Tanner (1630-92), Societas Jesu usque ad sanguinis et vitce profusionem militans [...] (Prague, 1675); see Festo Mkenda, "Jesuits and Africa," Oxford Handbooks Online, available online at http://www.oxfordhandbooks.com/view/10.1093/ oxfordhb/9780199935420.001.00o1/oxfordhb-9780199935420-e-56 (accessed June 24, 2017).

14 Malta Protestant College, Journal of a Deputation Sent to the East by the Committee of the Malta Protestant College in 1849 [...], 2 vols. (London: James Nisbet and Co., 1854), 2:849-50. 
their contentions hardly reached the outside world in any shape; there was then no public opinion to consider. Now the case is different. The various Missions of Rome are working in the same fields with Protestants; they are under constant surveillance, and whatever amount of bitterness or jealousy may exist among the rivals, it has, as far as possible, to be suppressed in the face of what they deem the common enemy. ${ }^{15}$

That description of a shared missionary field, mutual surveillance, and a combination of bitterness and jealousy that was sometimes tempered with the necessity of collaborating in a foreign milieu viewed as a common enemy perfectly suits the next wave of evangelization in Africa, which started toward the end of the eighteenth century and became intense in the nineteenth.

By this time, Portugal had already lost its exclusive hold on Africa, and more colonizing nations of Europe were bidding to acquire portions of the continent. Concomitantly, shades of Christianity other than Catholic and Orthodox were also seeking a foothold in Africa. This third wave of evangelization was pioneered by Protestants. They had just organized themselves for the missions, and Africa was clearly in their sights: 1792 saw the beginnings of the Baptist Missionary Society (BMS) under William Carey (1761-1834); the London Missionary Society (LMS) (bringing together Methodists, Presbyterians, and Congregationalists) started in 1795; the CMS started in 1799; the British and Foreign Bible Society (вғBS) started in 1804; and the Universities Mission to Central Africa started around 1857. These organizations sent missionaries to Africa, opening the era of multidenominational evangelization that continues to mark African Christianity to this day. "The year 1792 may be taken as the starting point of the epoch," observes historian John Baur (1920-2003), as "it saw the foundation of the first Protestant missionary society to work in Africa, the Baptists; the definitive establishment of the first mission in South Africa, the Moravian Genadental [sic]; and the foundation of Freetown in Sierra Leone as a base of Protestant mission work in West Africa."16

Protestant pioneering gives credence to the argument that, at least partly, Catholics resumed missionary activity in Africa in the nineteenth century in order to challenge a growing Protestant monopoly over the continent. ${ }^{17}$

$15 \mathrm{~K}$, "On the Character of Jesuit Missionary Teaching," Church Missionary Intelligencer and Record (July 1886): 529-45, here 543 .

16 Baur, 2000 Years of Christianity, 101.

17 See Ronald Werner, William Anderson, and Andrew Wheeler, Day of Devastation, Day of Contentment: The History of the Sudanese Church across 2000 Years (Nairobi: Paulines Publications Africa, 200o), 131; also see Noble, Redemption of Africa, 369 . 
While Protestant missionary societies were mostly organized by lay men and women, Catholics looked to clerical societies and to religious congregations for labor in mission territories. Many of them started in the nineteenth century and quite a few specifically focused on Africa: in 1802, the Holy Ghost Fathers, previously suppressed during the French Revolution, were restored by Napoleon Bonaparte (1769-1821) to educate the clergy for French colonies; in 1807, the Sisters of St. Joseph of Cluny were founded to serve in Africa and Asia; in 1814 , the Society of Jesus was restored; in 1841, Fr. Francis Libermann (1802-52) founded the Congregation of the Holy Heart of Mary specifically for the conversion of "Negroes"; in 1856, the Society of African Missions was founded by Melchior de Marion Brésillac (1813-59); in 1862, the Congregation of the Immaculate Heart of Mary (the Scheut Fathers); in 1866, the Mill Hill Fathers; in 1867, the Comboni Missionaries, specifically for missions in Sudan; in 1868, the White Fathers or Society of Missionaries of Africa, and in 1869, the Missionary Sisters of Our Lady of Africa, both founded by Lavigerie; and in 1875, the Society of Divine Word.

This combined Protestant and Catholic focus on nineteenth-century Africa led to a veritable missionary scramble not too different from the political scramble that preceded formal colonial occupation in that same century. Commenting on Catholic success in that scramble, Noble says the Catholic Church partitioned Africa into a number of ecclesiastical jurisdictions. Reporting on the same phenomenon, the mission-magazine of the Scotch Free Presbyterians stated that "whatever one might think about the papacy he could not but admire the daring of its schemes for the conquest of Africa."18 Indeed, while we can identify only around fifteen Catholic ecclesiastical jurisdictions in the whole of Africa from the first century of Christianity to the end of the eighteenth century, between 1818 and 1906 we can count up to sixty-six similar jurisdictions under different titles (mission, prefecture apostolic, vicariate apostolic, bishopric or archbishopric, diocese) under the care of twenty-one different missionary groups. ${ }^{19}$

Whether Catholics or Protestants, "missionaries were expected to carry and brandish the national flag," ${ }^{20}$ a fact that added a tint of patriotism to their competition for African souls. Even if violent encounters did not occur, subtle understatements and outright disparagements betray the disdain with which Christians of different denominations treated each other in Africa.

\footnotetext{
18 Noble, Redemption of Africa, 402.

19 See "Catholic Africa" in Catholic Encyclopedia, 1913 edition.

20 John W. O'Malley, A History of the Popes: From Peter to the Present (Lanham, MD: Sheed \& Ward, $2011[2010]), 251$.
} 
Commenting on early nineteenth-century Protestant missions in Algeria, for example, Thomas William Marshall (1818-77), himself a convert from Anglicanism, says the assertion that through Protestant preaching "many a son of Abraham had been made acquainted with the Redeemer" amounts to nothing more than "the statement, that several hundred copies of the Holy Scriptures had been circulated." ${ }^{21}$ Elsewhere, he retells an allegation, attributed to an Ethiopian Orthodox cleric, that Bibles distributed by Protestants ended up being used for "the wrapping up of snuff."22 Rather gleefully, he writes about a Protestant project in Algiers "to 'erect an edifice' for a church, which [...] would effectually stop 'the taunt in the mouths of the French Roman Catholics against British Protestants," yet whose results did not measure up to their lofty hopes. ${ }^{23}$ Lamenting what he viewed as English Methodists' interference with Catholic chances to unite Alexandria with Rome, Marshall summarily concludes: "It is the mission of Protestantism to scatter and destroy."24

Marshall's chapter on missions in Africa, written in 1862 and spanning 132 pages, was designed to provide a comprehensive overview of the subject from a Catholic point of view. As such, it contrasts sharply with that of Noble, written around 1899. Noble, who wrote on the same subject from a Protestant perspective, knew Marshall's work and referred to its author as "a professional apologist for papal missions." ${ }^{25}$ His fifty-eight-page chapter entitled "Rome in Africa" contains twenty-two pages entirely dedicated to the Jesuits and aptly subtitled "The Societas Jesu and Africa." Writing at the height of the political and economic scramble for Africa, ${ }^{26}$ Noble reveals the patriotic tint that characterized encounters between Catholics and Protestants in Africa. "France abroad has since the fall of Spain been the strong son of the church and uses papal missioners as political agents," argued Noble, citing Les missions catholiques for an affirmation "that French missioners 'go from pole to pole to teach knowledge and love of France as well as of the church."'27 In his narrative, the height of the nationalistic competitions is best seen in Uganda where "French priests arrived avowedly to oppose the Protestants by promulgating the truth as

\footnotetext{
21 Thomas William Marshall, Christian Missions: Their Agents, their Method, and their Results, 3 vols. (London: Burns and Lambert/H. Goemaere, 1862), 2:306-7.

22 Ibid., 347.

23 Ibid., 307.

24 Ibid., 309. The pages following this contain Marshall's diatribe against the Protestants, especially lamenting their conduct in Egypt and in other parts of Africa.

25 Noble, Redemption of Africa, 376.

26 See Thomas Pakenham, The Scramble for Africa 1876-1912 (London: Weidenfeld and Nicolson, 1992).

27 Noble, Redemption of Africa, 403.
} 
understood by members of their creed." The French priests, he says, "never concealed their enmity, if not to the Englishmen, [then] to their teachings." ${ }^{28}$ "The Algerine [White] Fathers, apart from their religious objects, were notoriously part of a plan to extend French influence," he further argues, which leads him to the conclusion "that the French priests were intended to win Uganda for France and to destroy the Protestant mission."29 Interestingly, the CatholicProtestant contest in Uganda was momentarily resolved by drawing denominational boundaries that were clearly marked by nationalistic sentiments, as Noble observes:

Not until Lugard took possession for the British company, did order come from chaos. The outcome of the horror is that in 1892 the agents of France and Rome were assigned with their converts to Buddu province, while Uganda proper was set apart for the Protestants. Cardinal [Herbert] Vaughan [1832-1903] afterward agreed to send missioners trained in his college to work with their French fellow Catholics, and it was hoped that this arrangement would remove the racial difficulty; but it failed of the success expected, and now Rome is replacing her Frenchmen wholly with English Catholics. The French realize the force of pax Britannica, and are convinced that Uganda belongs to Britain. ${ }^{30}$

More specifically to Jesuits, patriotic sentiments of this nature manifested themselves vividly in Madagascar, where mainly French Jesuits competed with mainly English Protestants for control of the local political establishment; and in Congo, where Protestants of different nationalities decried a close association between Belgian Jesuits and the Belgian colonial administration. In the latter case, Jesuits were perceived to be receiving material favors from the state in exchange for silence over state-sanctioned atrocities against native Africans. $^{31}$

28 Ibid.

29 Ibid., 404.

$30 \quad$ Ibid., 409-10. Lord Frederick Lugard (1858-1945) was hired by the Imperial East Africa Company in 1889 and, in the following year, "the company sent him to establish its authority in the Kingdom of Buganda in today's Uganda. There he intervened in a civil war among Ganda religious factions and persuaded Apolo Kagwa and other Ganda chiefs to accept British protectorate." Mark R. Lipschutz and R. Kent Rasmussen, Dictionary of African Historical Biography, 2nd ed. (London: University of California Press, 1986), 126.

31 See Marvin D. Markowitz, "The Missions and Political Development in the Congo," Africa: Journal of the International African Institute 40, no. 3 (1970): 234-47. 
As should be clear by now, in the missionary competitions that marked the nineteenth century, Jesuits were neither the only Catholic players in Africa nor the most dominant ones. Of the sixty-six ecclesiastical jurisdictions mentioned above, Jesuits manned only three: the vicariate apostolic of Central Madagascar, erected in 1848; the Zambezi mission, erected in 1879; and the Kwango mission in today's Democratic Republic of Congo (D RC), erected in 1892. However, these were vast missionary territories. The Zambezi mission, for example, was intended to cover most of southern Africa below the Equator. Moreover, as we cross to the twentieth century, Jesuit activity in Madagascar and in the DRC spread far beyond their initial centers. It follows that significant encounters between Jesuits and Protestants are to be observed within these three regions, and some of them are treated more specifically by different authors in the present volume. A more general look at the encounters could be narrowed down to six items that either forced Jesuits and Protestants to encounter one another or called for comment from one side about the other: memory, territory, government, people, theology, and method.

As already discussed, Jesuits had been in Africa in earlier centuries. While Jesuits themselves remain largely silent about this part of their history, other Catholics and Protestants dug out their memory and debated their legacy. Viewed through Catholic eyes, and with emphasis on the challenging context of the time, the first Jesuit experience in Ethiopia, Mozambique, and Angola was largely successful and its protagonists were heroes if not martyrs. ${ }^{32}$ Jesuits themselves felt comfortable with this Catholic point of view. Conversely, viewed through Protestant eyes, the experience was almost a complete failure. To cite Noble again, Jesuit converts in Africa "were but the most nominal Christians," and the Jesuit missionary system was "rotten from cornerstone to turret." ${ }^{33}$ Nearly all Protestant authors make reference to Jesuit implication in the slave trade as one reason for their failure in Angola and Mozambique. Yet, Protestant adherence to the Christianity-commerce-civilization triad as constituting a single missionary package ${ }^{34}$ forced even the loudest critic of the Jesuits to single out things they might have gotten right in earlier

32 Marshall, Christian Missions, 322-28; also see Jean Baptiste Coulbeaux, Histoire politique et religieuse de l'Abyssinie depuis les temps les plus reculés jusqu'à l'avènement de Ménélick II, 3 vols. (Paris: Geuthner, 1928), 2:132-63.

33 Noble, Redemption of Africa, 372.

34 Cf. Andrew Porter, Religion versus Empire? British Protestant Missionaries and Overseas Expansion, 1700-1914 (Manchester and New York: Manchester University Press, 2004), 92-96; also see David Livingstone, David Livingstone and Cambridge: A Record of Three Meetings in the Senate House (London: Universities Mission to Central Africa, 1908), 9, 12-13. 
times, mainly education of native Africans ${ }^{35}$ and direct involvement in agriculture and commerce. ${ }^{36}$

In the nineteenth century, shared territory became another cause of JesuitProtestant encounter in Africa. To the missionary, Africa was an open field, a territory free to be grabbed. Whoever arrived first was inclined to claim exclusive rights to evangelize within a given geographical area and to view the next Christian comer as an intruder. However, neither Jesuits nor Protestants were able effectively to cover the mammoth territories they had mapped for themselves. In 1905, Joseph Moreau (1864-1949), one of the Jesuit pioneers in Zambia, would muse: "Very few then realized the vastness of the territory assigned to the Zambezi Mission. Who was to undertake a work of such magnitude as to evangelise this vast territory?" Moreau observed that "Catholic and Protestant missionaries had already established Mission Stations in the Cape Colony, Natal, and Basutoland." Moreover, the "London Mission Society had a wellestablished mission station among the Bechwana [...] [and] Rev. Moffat and family had settled at Inyati [among the Matabele]." He further observed that, northward beyond the Zambezi, "among the Barotse, no missionary had as yet got a foothold." The decision of the Propaganda in Rome to erect the Zambezi mission was not only for the purposes of reaching where no missionary had yet gotten a foothold but "for the evangelization of those vast territories which had not yet been contacted by the Catholic Church, and only slightly so by the Protestants." ${ }^{37}$ In fact, Jesuit attempts to settle in present-day Zambia, which started in the late nineteenth century but succeeded only in 1905, were interferences in regions that had been more than just slightly contacted by Protestants. ${ }^{38}$ Making reference to the experience in the realm of Chief Khama III (c.1835-1923, r.1872-73, 1875-1923) of the Bangwato people of central Botswana, Noble complained that the Jesuits "had long known that Shoshong was the headquarters of the British Congregationalists in the interior," but still "aimed

35 See Isaac Schapera, ed., David Livingstone: Family Letters 1841-1856, 2 vols. (London: Chatto \& Windus, 1959), 2:255; also see Noble, Redemption of Africa, 372.

36 See David Livingstone, Missionary Travels and Researches in South Africa: Including a Sketch of Sixteen Years' Residence in the Interior of Africa (London: Ward, Lock \& Co., 1857), 346; Schapera, David Livingstone, 2:277; Noble, Redemption of Africa, 380.

Joseph Moreau, "The Chikuni Mission: How It Came to Be" (unpublished manuscript dated 1905, copy at the Jesuit Historical Institute in Africa), 1-2; also see Michael Gelfand, ed., Gubulawayo and Beyond: Letters and Journals of the Early Jesuit Missions to Zambesia (1879-1887) (London: Geoffrey Chapman, 1968), 18-19.

38 See Reinhard Henkel, Christian Missions in Africa: A Social Geographical Study of the Impact of Their Activities in Zambia (Berlin: Dietrich Reimer Verlag, 1989), 28-32. 
to plant a Jesuit station among the Mangwato."39 Under such circumstances, it was inevitable that Jesuits and Protestants would rub together in the territories they sought to evangelize.

Territory and government were closely linked. Generally, the task of governing in nineteenth-century Africa was carried out by chiefs of various ranks. In order to settle and evangelize in a particular area, missionaries had to deal directly with these chiefs. Their success or failure depended heavily on the favor or ill-will of the chiefs. Moreover, as historian Stephen Neill indicates:

Various motives encouraged chiefs to permit the presence of missionaries among their people. Some were clever enough to recognize that a white man might be useful as a safeguard against the ever-encroaching menace of his fellow-countrymen. Others regarded him merely as a convenient milch-cow from whom endless gifts and tribute could be extracted. Others again liked to have a tame missionary about the place as they might equally well have liked to have a tame elephant. But, whatever the motive, without the approval of the chief residence was impossible, and, even if residence was permitted, the acquisition of land on anything like a permanent tenure was always a matter of the utmost difficulty. 40

As long as they went to the same places, Jesuits and Protestants had to deal with the same chiefs. The chief became the point of their encounter and, in many ways, the arbitrator between them.

In allocating land, the chief decided who settled where in order to separate competing missionary interests. Moreau's narrative of the first Jesuit encounter with Chief Khama is of interest in this regard. Khama was already a Christian aligned to the LMs. When Jesuits approached him for permission to settle and preach, Khama

answered that he had already the missionaries of the London Missionary Society, that either Fr. Depelchin's missionaries would teach the same doctrine, and therefore would be no new acquisition, or they would teach a different one, and thereby bring disunion among his people, and would in such a case be worse than useless. ${ }^{41}$

39 Noble, Redemption of Africa, 387.

40 Stephen Neill, A History of Christian Missions (Harmondsworth: Penguin, 1964), 371.

41 Moreau, "Chikuni Mission," 4. Henri Depelchin (1822-1900) was the first Jesuit superior of the Zambezi mission. 
From Khama's territory, the Jesuits proceeded to Chief Lobengula (c.1836-94, r.1870-94) of the Ndebele people in today's Zimbabwe. Here, according to their host, they could stay, repair his wagon, teach his people different trades, and even repair guns, "but not teach his people any doctrine that condemned the laws or customs of his country." The Jesuits, like the Protestants who had arrived in Matabeleland before them, were forced to sit and wait for better times. ${ }^{42}$ In fact, it has been argued that "Lobengula used his experience with Protestant missionaries and European traders to develop an effective strategy that severely limited the efficacy of the Jesuits' efforts." ${ }^{33}$ The Jesuits also visited Chief Lewanika (c.1842-1916, r.1878-84, 1885-1916) of the Lozi people in today's Zambia, first in 1880, when they found him disposed to their mission, then in 1883 , when he was no longer interested in them. Their conclusion: "Influences had been at work meanwhile pre-disposing him against the Catholic missionaries and inclining him towards the Protestants." 44

At some point, missionaries all over Africa were of the opinion that "better times" could be made to come faster than they would naturally do. Jesuits and Protestants in southern Africa came to view obdurate African chiefs as irritants if not outright obstacles to the Gospel. Historian James Morrison would describe the African "tribal chief" as "often a cruel, bloodthirsty and licentious tyrant who ate up his people." ${ }^{45}$ Such chiefs kept their people out of the missionary's reach, ${ }^{46}$ it was thought, yet it was the African native that the missionary wished to evangelize. Noble, the avowed critic of Catholic missions in Africa, would say that the "Jesuits also believed, and rightly, that the difficulty of missions among the Tabili [Ndebele] lay in the government rather than the subject [...]. If despotic institutions could be relaxed, here was a soil capable of fruit." He further cites Alfred Weld, s.J. (1823-90) as having "thought it 'probable that if we set aside the influence of despotic rule, which may itself be turned to good, the field is more hopeful than that of the Parana and Uruguay which produced so rich a harvest." 47 Obviously, an alternative to the despotic chiefs was a colonial administration that would provide protection for missionaries, freedom for the native African to convert, and freedom of religion to

\footnotetext{
42 Neill, History of Christian Missions, 4-5.

43 Nicholas M. Creary, Domesticating a Religious Import: The Jesuits and the Inculturation of the Catholic Church in Zimbabwe, 1879-1980 (New York: Fordham University Press, 2011), 26.

44 Moreau, "Chikuni Mission," 9.

45 J.H. [James Horne] Morrison, The Missionary Heroes of Africa (New York: George H. Doran Company, 1922), 21.

46 See Creary, Domesticating a Religious Import, 27.

47 Noble, Redemption of Africa, 390-91.
} 
Catholics and Protestants akin to what had become commonplace in Europe and America at that time. Again, a typical example of this case is that which involved Lobengula. Through a concession that was wrongly interpreted and explained to him by Rev. Charles Helm (1844-1915) of the LMS, the chief had allegedly paved the way for Cecil Rhodes's (1853-1902) British South Africa Company (BSAC) that enjoyed the services of Jesuit chaplains to occupy and administer territories far beyond his own control.48 "You've done a good day's work for Rhodes, padre, and he won't forget it; a good day's work for your mission too," said James Maguire (1855-1945), one of the negotiators of the 1888 Rudd Concession, in gratitude to the Protestant missionary misinterpreter. ${ }^{49}$

The Ndebele did resist the colonial take over implied in the Rudd Concession, but they were subdued through military campaigns in 1893 and 1896, which also enjoyed Jesuit chaplaincy. "The Catholic [read: Jesuit] priest had the privilege of being present at all these engagements," reported Marcus Barthélemy, S.J. (1857-1913), who also noted that the Catholic chaplain catered for the spiritual needs of Protestants and "heathens" as well:

The Protestant was glad to see near him the minister of God and to be helped to form a good act of faith and of contrition before appearing at the tribunal of God; the Catholics received the precious sacraments which our Holy Mother Church dispenses to her dying children, and several poor heathens of our native contingent were privileged to receive baptism before they succumbed to their wounds. ${ }^{50}$

In the end, not only Protestant missionaries benefited from the establishment of the BSAC-controlled colony of Rhodesia; Jesuits also "received extensive land grants to establish permanent mission stations in and around Salisbury and Bulawayo." ${ }^{1}$

Establishment of colonial administration also facilitated greater access to native Africans, the people that were the target of Catholic and Protestant evangelization. Despite their disapproval of each other's doctrines, "both sects had the same object in view, that of bringing a better life to the African,"

48 See ibid., $25,31^{-32 .}$

49 Hugh Marshall Hole, Lobengula (London: Philip Allan \& Co., 1929), 152-53.

5o Marcus Barthélemy, "During the Matabele Wars," Zambesi Mission Record 1 no. 1 (1898): 19-21, here 21.

$5^{1}$ Creary, Domesticating Religious Import, 32; also cf. Moreau, "Chikuni Mission," 10-11; Noble, Redemption of Africa, 383; Brendan P. Carmody, Conversion and Jesuit Schooling in Zambia (Leiden: Brill, 1992), 27. 
contends physician and historian Michael Gelfand (1912-85).52 Both targeted the same groups of people: the Ndebele, the Shona, the Tonga, the Lozi, and so on. As they competed for the same souls, Jesuits and Protestants had to prove their worth before the African. "Of course it can be argued that this competition had its advantages," says Gelfand, "for the presence of one group inevitably encouraged the efforts of the other and so their missionary activities were double." 53

In the main, Jesuits and Protestants had a shared view of the African as a heathen and an object of their separate civilizing missions. Greater access to people implied greater acquaintance with the cultures and traditions that the missionaries considered so antithetical to their Gospel. The missionary industry that is evident in the study of local languages, the translation of scriptures, and the documentation of native customs is an example of this increased acquaintance. The missionaries arrived at fairly similar conclusions and held the same theological views regarding African religious dispositions. As has been argued in a different context, nineteenth-century missionaries

identified Christianity with the moral standards of their own middleclass background at home, and anything which deviated from these standards, they regarded as sinful and deplorable and to be eradicated. They had very little appreciation or respect for the customs and traditions of the people. They condemned dancing, sports, smocking and many other innocent habits of the people, and regarded them as harmful to Christianity and therefore forbidden to the members of the society. ${ }^{54}$

Despite their overall reputation as generally tolerant of other cultures and, as such, ahead of their time on matters of inculturation, ${ }^{55}$ Jesuits struggled with certain elements of traditional African society. Reporting on the "Kaffirs" of South Africa, Charles Bick, S.J., (1861-1939) reduced these to the practice of polygamy, the relationship with ancestral spirits, and the belief in malevolent forces of witchcraft and sorcery. ${ }^{56}$ Protestants shared in this theological assessment. Talking about the same group of native Africans, Bishop Joseph Watkin Williams (1857-1934) of the Anglican diocese of St. John's, Kaffraria, declared

$5^{2}$ Gelfand, Gubulawayo and Beyond, 20.

53 Ibid.

54 Sione Latukefu, "The Case of the Wesleyan Mission in Tonga," Journal de la Société des océanistes 25 no. 25 (1969): 95-112, here 97.

55 Cf. Thornton, "Conquest and Theology."

$5^{6}$ Charles Bick, "The Missions of Kaffraria," Zambesi Mission Record 1, no. 1 (1898): 27-34. 
polygamy to be "undoubtedly the most formidable question with which the missionary has at present to deal."57

The seeming theological unanimity just described did not create communion, however. There were significant Catholic and Protestant voices blaming the opposite side for allowing too much of African practice into Christianity. Robert Sykes, S.J. (1854-1920), twice superior of the Zambezi mission, dismissed the Protestant native as one who "seems to have inherited with his reception into the Christian body, a double dose of original sin," becoming worse than he or she was in his or her "heathen" state. "If this is the result, what is the value of missionary effort, and why teach the native 'Christianity' at all?" asked Sykes. ${ }^{58}$ His question almost lends credence to Noble's complaint that Catholics "believed it better the natives should remain heathens than imbibe [Protestant] heresy" ${ }^{59}$ In Catholic eyes, Noble would argue, Protestantism was a heresy, and Catholic "entrance into Protestant mission-fields is an inevitable, logical outcome from her principle and practice of including Protestant heretics with heathen lands." ${ }^{\circ 0}$ However, Noble also viewed the work of the Protestant missionaries as being far more effective than that of their Catholic counterparts. For him, "the Jesuit was lax or strict according to circumstance, a moral chameleon" whose objective "was to drive no person from the church." Consequently, "since there are bad people, it is better they should be poor Catholics than wicked Protestants, a sentiment many non-Romanists will endorse in a sense the reverse of that intended by Jesuistry." ${ }^{\prime 1}$ It is no surprise that, as was noted earlier, Noble himself viewed the Jesuits' African converts as the most nominal of Christians. "Rome was numerically more powerful," he argued, "but the weight of character and influence rested with the Protestants." 62

Finally, Jesuits and Protestants commented on each other's missionary methods, sometimes commending them, other times disapproving of them. For example, there was a certain understanding among Jesuits, shared by other Catholics as well, that Protestants used money to advance their course, and

57 The bishop of St. John's, Kaffraria, "Law and Customs of Marriage in Non-Christian Lands (S. Africa or Africa) as Bearing on Mission Difficulties," in Pan-Anglican Congress, The Church and Human Society: Speeches and Discussions together with the Papers Published for the Consideration of the Congress (London: Society for Promoting Christian Knowledge, 1908), Part 2, 13-20, here 13 .

58 Robert Sykes, "Protestant Missionary Activity in South and Central Africa," Zambesi Mission Record 1, no. 1 (1898): 11-15, here 11.

59 Noble, Redemption of Africa, 402-3.

6 o Ibid., 363 .

61 Ibid., 372.

62 Ibid., 409. 
that they had a lot of it. According to Sykes, Protestant "propaganda" was "supported by immense sums of money annually contributed by charitablydisposed Protestants at home, which are not, as far as I am aware, restricted to any particular sect, but a proportion of which finds its way into the coffers of the different missionary bodies in Africa." ${ }^{63}$ But, starting with David Livingstone (1813-73), ${ }^{64}$ nearly all Protestants in Africa also believed that Jesuits had incredible amounts of wealth. "The Societatis Jesu is fancied to be inordinately wealthy," wrote Noble several decades after Livingstone. ${ }^{65}$ More generally, some of them believed that the Propaganda Fide poured immeasurable sums of money into missions, so much so that apparent nineteenth-century Catholic success in places like Ethiopia was attributed "principally to bribery and corruption." 66

While we may never settle the argument about who had more wealth, we may safely conclude that both Jesuits and Protestants used money and other resources to establish the "missions" or "mission stations" that had become the preferred locus of Christian activity, together with the schools and hospitals that were constitutive elements of those missions and stations. ${ }^{67}$ Some Protestants would argue that Jesuit missionary method went beyond the mission-station model to establish "Christian villages." The fullest development of this Jesuit structure in Africa was seen in the so-called "chapel-farms" in Congo, which were created exclusively for the youth, with each consisting of a chapel, a missionary lodge, a farm, and accommodation for children and for a few married couples that were meant to be role models for the targeted boys and girls. The "chapel-farms" attracted a lot of criticism from Protestants who viewed them as a re-creation in Africa of the "reductions" of Paraguay, a charge the Jesuits denied vehemently. ${ }^{68}$

Given the mutual suspicion between Catholics and Protestants in Africa, a general overview like this can easily fail to notice moments of friendship, support, collaboration, and appreciation that were not entirely lacking among the missionaries across the denominational divide. Despite his critical stance against anything Protestant, for example, Marshall could still describe a certain

63 Sykes, "Protestant Missionary Activity," 12.

64 Livingstone, Missionary Travels, 551.

65 Noble, Redemption of Africa, 367.

66 John Wilson, The Lands of the Bible, 2 vols. (Edinburgh: William Whyte \& Co., 1847), 2:593.

67 Henkel, Christian Missions in Africa, 24-25.

68 Noble, Redemption of Africa, 383; also see "The Catholic Missions in Belgian Congo: A Statement of Facts," The Tablet 119, no. 3741 (January 20, 1912): 106-10, and Emile Thibaut, Les fermes-chapelles: A propos d'un débat recent (Brussels: Goemaere, 1911). 
Mr. Bell, who was an English Protestant, as "friend and protector" of Catholic missionaries. ${ }^{69}$ In so doing, Marshall revealed a close racial or cultural affinity among missionaries of various denominations as they encountered one another in what was to them a hostile environment populated by strange peoples with foul cultures. The competent guide of the Jesuits' caravan across Tongaland was one Mr. Walsh Pan, an Irish Protestant married to a Catholic wife, whom the Jesuits later re-baptized into Catholicism while he was in danger of death. ${ }^{70}$ Catholics too performed charitable acts toward their Protestant counterparts. Noble tells us that, when the Presbyterian bishop Alexander Mackay (1849-90) died in Uganda, "a papal missionary was hastening as a good Samaritan to nurse him."71 Moreover, although Noble criticized the Jesuits, he ultimately viewed them in a more positive light than other Catholic missionary groups: "While the Jesuits developed the positive qualities of energy," he said, "the Capuchins gave expression to the negative qualities of ignorance, credulity and coarse sympathy with the lower instincts of the masses. ${ }^{72} \mathrm{He}$ even defended Jesuits against the now accepted charge that, in Africa, they engaged in or tolerated the slave trade, proposing instead that the charge "is probably as false as the modern scandals occasionally retained against their Protestant brethren."73

To a contemporary ear accustomed to hearing about positive efforts toward ecumenism, the largely fractious encounters between Jesuits and Protestants in Africa may be surprising. Yet, ecumenism, implying unity among Christians pursued across the boundaries of creed, ritual, and polity, is a twentieth-century phenomenon. Although Protestant missionary associations in the nineteenth century showed remarkable interest in interdenominational collaboration, it was still unthinkable that Catholics and Protestants could come together on matters that had implications for doctrine. Nineteenth-century Jesuit and Protestant missionaries in Africa belonged to their time. For this very reason, the few recorded cases of collaboration and mutual appreciation, though more personal than institutional, and even though almost completely lost in an ocean of suspicion and negative comment, should probably be accorded preferential weighting in any analysis of Christian denominational encounters in Africa.

69 Marshall, Christian Missions, 337.

70 Véronique Wakerley, trans., Journeys beyond Gubulawayo to the Gaza, Tonga and Lozi: Letters of the Jesuits' Zambesi Mission, 1880-1883, ed. R.S. Roberts (Harare: Weaver Press, 2009), 96-97.

71 Noble, Redemption of Africa, 409.

72 Ibid., 393 .

73 Ibid., 381. 


\section{Bibliography}

Barthélemy, Marcus. “During the Matabele Wars.” Zambesi Mission Record 1 no. 1 (1898): 19-21.

Baur, John. 2000 Years of Christianity in Africa: An African Church History. 2nd ed. Nairobi: Paulines Publications Africa, 2009 [1994].

Beckingham, C.F. [Charles Fraser], and G.W.B. [George Wynn Brereton] Huntingford. "Introduction." In Some Records of Ethiopia, 1593-1646: Being Extracts from The History of High Ethiopia or Abassia by Manoel de Almeida Together with Bahrey's History of the Galla, translated and edited by C.F. [Charles Fraser] Beckingham, and G.W.B. [George Wynn Brereton] Huntingford, xxi-xlix. Aldershot and Burlington: Ashgate, 1954 .

Bick, Charles. “The Missions of Kaffraria." Zambesi Mission Record 1, no. 1 (1898): 27-34. Carmody, Brendan P. Conversion and Jesuit Schooling in Zambia. Leiden: Brill, 1992.

Chadwick, Hubert. Life of the Venerable Gonçalo da Silveira of the Society of Jesus: Pioneer Missionary and Proto-martyr of South Africa. London: Manresa Press, 1910.

Coulbeaux, Jean Baptiste. Histoire politique et religieuse de l'Abyssinie depuis les temps les plus reculés jusqu'à l'avènement de Ménélick II. 3 vols. Paris: Geuthner, 1928.

Creary, Nicholas M. Domesticating a Religious Import: The Jesuits and the Inculturation of the Catholic Church in Zimbabwe, 1879-1980. New York: Fordham University Press, 2011.

Gelfand, Michael, ed. Gubulawayo and Beyond: Letters and Journals of the early Jesuit Missions to Zambesia (1879-1887). London: Geoffrey Chapman, 1968.

Guilday, Peter. "The Congregation de Propaganda Fide (1622-1922)." Catholic History Review 6, no. 4 (1921): 478-94.

Henkel, Reinhard. Christian Missions in Africa: A Social Geographical Study of the Impact of Their Activities in Zambia. Berlin: Dietrich Reimer Verlag, 1989.

Hole, Hugh Marshall. Lobengula. London: Philip Allan \& Co., 1929.

K. "On the Character of Jesuit Missionary Teaching." Church Missionary Intelligencer and Record (July 1886): 529-45.

Latukefu, Sione. "The Case of the Wesleyan Mission in Tonga." Journal de la Société des océanistes 25 no. 25 (1969): 95-112.

Lipschutz, Mark R., and R. Kent Rasmussen. Dictionary of African Historical Biography. 2nd ed. London: University of California Press, 1986.

Livingstone, David. David Livingstone and Cambridge: A Record of Three Meetings in the Senate House. London: Universities Mission to Central Africa, 1908.

Livingstone, David. Missionary Travels and Researches in South Africa:Including a Sketch of Sixteen Years' Residence in the Interior of Africa. London: Ward, Lock \& Co., 1857.

Livingstone, David, and Charles Livingstone. Narrative of an Expedition to the Zambesi and Its Tributaries; And of the Discovery of the Lakes Shirwa and Nyassa, 1858-1864. London: John Murray, 1865. 
Lobo, Jerome. A Voyage to Abyssinia. Translated by Samuel Johnson. London: Elliot and Kay, 1789 .

MacCulloch, Diarmaid. A History of Christianity: The First Three Thousand Years. London: Penguin Books, 2009.

Malta Protestant College. Journal of a Deputation Sent to the East by the Committee of the Malta Protestant College in 1849 [...]. 2 vols. London: James Nisbet and Co., 1854. Markowitz, Marvin D. “The Missions and Political Development in the Congo." Africa: Journal of the International African Institute 40, no. 3 (1970): 234-47.

Marshall, Thomas William. Christian Missions: Their Agents, their Method, and their Results. 3 vols. London and Brussels: Burns and Lambert and H. Goemaere, 1862.

Mkenda, Festo. "Jesuits and Africa." Oxford Handbooks Online; available online at http:// www.oxfordhandbooks.com/view/10.1093/oxfordhb/9780199935420.001.00o1/ oxfordhb-9780199935420-e-56 (accessed June 24, 2017).

Morrison, J.H. [James Horne]. The Missionary Heroes of Africa. New York: George H. Doran Company, 1922.

Neill, Stephen. A History of Christian Missions. Harmondsworth: Penguin, 1964.

Ngetich, Elias Kiptoo. "Catholic Counter-Reformation: A History of the Jesuits' Mission to Ethiopia 1557-1635." Studia historiae ecclesiasticae 42, no. 2 (2016): 104-15.

Noble, Frederic Perry. The Redemption of Africa: A Story of Civilization. 2 vols. New York: Young People's Missionary Movement, 1899.

O'Malley, John W. A History of the Popes: From Peter to the Present. Lanham, MD: Sheed \& Ward, 2011 [2010].

Pakenham, Thomas. The Scramble for Africa 1876-1912. London: Weidenfeld and Nicolson, 1992.

Porter, Andrew. Religion versus Empire? British Protestant Missionaries and Overseas Expansion, 1700-1914. Manchester and New York: Manchester University Press, 2004.

Schapera, Isaac, ed. David Livingstone: Family Letters 1841-1856, 2 vols. London: Chatto \& Windus, 1959.

Sykes, Robert. "Protestant Missionary Activity in South and Central Africa." Zambesi Mission Record 1, no. 1 (1898): 11-15.

Tachard, Guy. A Relation of the Voyage to Siam: Performed by Six Jesuits Sent by the French King, to the Indies and China in the Year 1685. Bangkok: White Lotus Press, 1999 [1688].

Thibaut, Emile. Les fermes-chapelles: A propos d'un débat récent. Brussels: Goemaere, 1911.

Thornton, John K. "Afro-Christian Syncretism in the Kingdom of Kongo." Journal of African History 54, no. 1 (2013): 53-77.

Thornton, John K. "Conquest and Theology: The Jesuits in Angola, 1548-1650." Journal of Jesuit Studies 1 (2014): 245-59. 
Wakerley, Véronique, trans. Journeys beyond Gubulawayo to the Gaza, Tonga and Lozi: Letters of the Jesuits' Zambesi Mission, 1880-1883. Edited by R.S. Roberts. Harare: Weaver Press, 2009.

Werner, Ronald, William Anderson, and Andrew Wheeler. Day of Devastation, Day of Contentment: The History of the Sudanese Church across 2000 Years. Nairobi: Paulines Publications Africa, 2000.

Wilson, John. The Lands of the Bible. 2 vols. Edinburgh: William Whyte \& Co., 1847. 